\title{
Jurassic Pork: What Could a Jewish Time Traveler Eat?
}

\author{
Roy E. Plotnick ${ }^{1^{*}} \mathbb{D}$, Jessica M. Theodor ${ }^{2}$ and Thomas R. Holtz Jr.
}

\begin{abstract}
Paleontologists use multiple methods to reconstruct the anatomy and behavior of extinct animals, including direct observations from well-preserved fossils and inferences from the phylogeny of modern and extinct relatives. We illustrate these techniques by reference to the biblical definitions of kosher and non-kosher animals; that is, how can we apply these approaches to the hypothetical question of whether an extinct form would have been kosher. The biblical categories do not readily map to modern understandings of systematics, but are heavily based on life mode. When given, distinguishing characteristics, such as the presence of fins and scales in aquatic animals, can be readily seen directly in fossils. In other cases, such as cud chewing, they need to be inferred from the phylogenetic relationships of the fossil forms. Dinosaurs (other than birds), unfortunately, are not kosher. A kosher "paleo diet" would be increasingly difficult further in the past. The use of biblical content as a way of introducing concepts from paleontology and evolutionary biology, such as crown groups and stem groups, should be of broad interest.
\end{abstract}

Keywords: Mammals, Insects, Birds, Dinosaurs, Fossil, Kosher

\section{Background}

A paleontologist colleague of ours was recently asked by a student whether brachiopods, an invertebrate group commonly preserved as fossils, were kosher. He posted the question on Facebook and the immediate response was "certainly not, brachiopods are shellfish!" This reminded one of us (JMT), a specialist on fossil hoofed mammals, of questions she has received on whether a particular ancient animal would have been kosher. Of course, whether or not a fossil animal would have been kosher is purely hypothetical; the surviving remains themselves would make a very poor meal. Nevertheless, discussing how paleontologists would address such a query illustrates how they think about the morphology, ecology, and relationships of extinct animals and thus gives an opportunity to introduce broader concepts from paleontology and evolutionary biology to a more general audience.

\footnotetext{
*Correspondence: plotnick@uic.edu

1 Department of Earth and Environmental Sciences, University of Illinois at Chicago, 845 W. Taylor St., Chicago, IL 60607, USA

Full list of author information is available at the end of the article
}

We will first review the basic characteristics that divide kosher from non-kosher animals. We will then discuss how these characteristics can be recognized or inferred in ancient fish, mammals, birds (and other dinosaurs), and insects. Note that we will not address the issue of why the rules exist or are followed or topics such as ritual slaughter or the separation of meat and milk (Donin 1972; Regenstein et al. 2003; Kraemer 2007; Zamore 2011a). We will then take a virtual time trip to different episodes of Earth history, to see what might be available for an observant Jewish time traveler to eat. Finally, we will comment on how one might use this topic in outreach and education.

\section{Is it kosher?}

The rules that govern whether an animal is ritually fit or proper (kosher) or unfit to eat are known as kashrut. Although kashrut is closely monitored by rabbinical authorities, a rabbinic "blessing" is not an intrinsic part of this (Telushkin 1991). Whereas these rules are of biblical origin, they have been interpreted, modified, and argued about over the long history of the Jewish people, up to this day (Kraemer 2007). Kashrut is based on sections of the Torah (Hebrew Bible), in particular Leviticus 
11 and Deuteronomy 14:2-21. The delineation of kosher vs. non-kosher is based either on required characteristics (simanim), a list of permitted or prohibited animals, or both. The division of animals into groups relies more heavily on life mode than on current recognized relationships; for example, animals are "in the waters" or "swarm upon the earth." The affinities of many of the listed animals with modern species and higher groups are questionable and sometimes differ significantly among translations (note: we are using the translation by the Jewish Publication Society 1985). Moreover, the animals listed also reflect only those that were familiar to people living in a small portion of the ancient Middle East. As the Jewish people dispersed, they encountered a huge variety of plants and animals that were new to them, in particular the New World. The kosher status of each of these had to be decided.

Kosher mammals ("beasts that are on the earth") "have true hoofs, with clefts through the hoofs, and that chews the cud" (Lev. 11:2; Deut. 14:6). Specifically permitted animals include oxen, sheep, goats, deer, gazelle, and mountain sheep (Deut. 14:4-5); however not all of these are confidently assigned to known species. Enumerated forbidden ("unclean") animals are camels, hares, daman (rock hyrax), and pigs. Camels, hares, and hyrax are said to chew the cud but lack true hoofs, whereas swine do not chew cud, although they have true hooves. Bats are also forbidden, although they are listed with birds ("fowls", Lev. 11:19; Deut. 14:18). Similarly, moles and mice are listed as prohibited among "things that swarm on the earth," all of which are forbidden (Lev. 11:20). Leviticus 11:27 adds that animals that walk on paws are also unclean. The existence of identifying characteristics made the identification of novel kosher mammals straightforward. Bison, for example, were quickly accepted as being kosher (Zivotofsky 1999).

In contrast to the identifying characteristics that are given for mammals, birds are simply enumerated and only those that are forbidden are named. Again, there is some uncertainty as to species identity. Forbidden birds include raptors (eagles, kites, falcons, hawks, and owls); vultures, ravens, pelicans, sea gulls, storks, herons, bustards, ostriches, cormorants, hoopoes, and bats (regarded as birds in this context, but of course not members of the group Aves). Newly encountered species with the same basic characteristics (birds of prey, scavengers, ratites) were similarly banned. Since identifying characteristics are not given, currently permitted birds are strongly based on documented tradition (mesorah); i.e., "we have always eaten them" (Hoffman 2010; Zamore 2011b). These include domesticated groups such as geese, most ducks, and pigeons. Turkeys, as New World birds, are late additions to this list and are not without controversy
(Regenstein et al. 2003; Zivotofsky 2014). Retrospectively, the scholars of the Talmud (the commentaries on the Torah) recognized some shared characteristics of permitted birds as a guide to use when tradition is uncertain (Brody 2011). We will discuss these in more detail later.

Similar to mammals, characteristics for aquatic life are clearly stated: "you may eat anything that has fins and scales." (Lev. 11:9, Deut. 14:9-10). Shellfish of all phyla are thus expressly forbidden, as are eels and catfish. Some debate surrounds the nature of scales. The Orthodox view is that proper scales (kaskeses; Orthodox Union 2013) must be able to be removed without tearing the underlying skin and be visible to the naked eye. Orthodox Jews thus usually accept only fish with surficial ctenoid or cycloid types of scales and reject sturgeons, which possess ganoid scales (Donin 1972; Regenstein et al. 2003). Because swordfish lose their scales during growth, many but not all Orthodox also reject them. Conservative rabbis permit both sturgeons and swordfish (Telushkin 1991). Neither group accepts the placoid scales of chondrichthyans (sharks and rays). We are not aware of any discussions of the cosmoid scales of sarcopterygians such as lungfish and coelacanths; it would have to be determined whether they can be removed without the tearing the skin. Aquatic mammals fall under the category of aquatic life and since they lack scales are not kosher.

Almost all other forms of terrestrial animal life are forbidden. Rodents, mustelids, and reptiles are among the unclean: "And these are they which are unclean unto you among the swarming things that swarm upon the earth: the weasel, and the mouse, and the great lizard after its kinds, and the gecko, and the land-crocodile, and the lizard, and the sand-lizard, and the chameleon (Lev. 11:29:30) ..." "Swarm on the earth" has also been translated as "creeping things that creep upon the earth" (King James Bible and elsewhere).

Nearly all insects are specifically prohibited in Leviticus (11:20 and 11:42): "All winged swarming things that go upon all fours are a detestable thing unto you... you shall not eat, among all things that swarm on the earth, or anything that walks on fours, or anything that has many legs." Why flying insects were identified as having four and not six legs is not clear but may be related to the section "but these you may eat among all the winged swarming things that walk on fours: all that have above their feet, jointed legs to leap with on the ground" (Lev. 11:21). In other words, those that have rear jumping legs in addition to four anterior legs. The section goes on to list specific permissible insects: "locusts of every variety; all varieties of bald locust; crickets of every variety; and all varieties of grasshopper." All of these are members of the Order Orthoptera. Since European Jewish communities have long lost the tradition of eating orthopterans, 
observant Jews of these groups tend to avoid them. They are, however, eaten among Yemenite and Moroccan Jews (Zamore 2011a). One Talmudic section indicates that grasshoppers can be eaten with cheese (Kraemer 2007) and are thus not considered meat. All other insects are unclean and the Orthodox carefully examine and remove visible insects from their fruits and vegetables (Regenstein et al. 2003).

In contrast, Islamic dietary laws are generally are more lenient in terms of permitted (halal) animals (Regenstein et al. 2003). The only animals the Quran specifically declares as haram (forbidden) are pigs and their relatives "forbidden to you are carrion and blood and swine flesh" (Quran 5:3). Camels, for example, are halal. Additional prohibitions stem from the Hadith, the reports of the sayings and practices of the Prophet Muhammed. These include proscriptions against carnivores, birds of prey, and animals that live part of their lives in both land and water (e.g., frogs, crocodiles, and seals). However, there are differences among different Muslim groups (for example, Sunni and Shia) on these and other prohibitions, such as on shellfish (Regenstein et al. 2003).

\section{Was it kosher?}

Determining whether a particular fossil animal would have been kosher depends on the group we are examining. For mammals, fish, and insects, it is an issue of whether we can determine the presence or absence of the simanim. In evolutionary biology, this is equivalent to determining the presence or absence of particular characters. In some cases the characters can be directly observed; in others, we have to use the tools of phylogenetic reconstruction to reliably determine their presence. Birds (and dinosaurs) are trickier; in this case, we will have to mainly argue from reconstructions of ecology and behavior. Of necessity, we will have to largely ignore the concept of mesorah; these ancient animals long predate anyone who would have had a tradition of eating them.

\section{Fish}

As a first approach, we will assume that if a type of fish is kosher today its ancestral relatives would have also been kosher. We can thus ask: what is the fossil record of kosher fish groups? A list of those fish today that are kosher and non-kosher and what taxonomic groups they belong to was prepared decades ago by James W. Atz, a curator of ichthyology of the American Museum of Natural History and is widely distributed online (e.g., http://www.kosherquest.org/bookhtml/FISH.htm). This list includes either the taxonomic family that the fish belong to (for example, Family Clupeida, the herrings) or a genus (Coryphaena, dolphin fishes) or even a species name (Dissostichus eleginoides-Chilean sea bass).
We compared the Atz list to that in the current Fishbase database (Froese and Pauly 2014) to determine if the family names listed by Atz were still in use and updated them where appropriate. For his genera and species, we used Fishbase to determine what family they belonged to. The families were then placed into the most recent classification of fishes based on molecular phylogenetic methods (Betancur et al. 2013). Finally, we used the Paleobiology Database (paleodb.org) to determine if these families had a fossil record. The Paleobiology Database is a community effort to produce a database of the occurrences of fossil organisms through time, space and environment.

Nearly all kosher fish belong to the Subclass Neopterygii of the Class Actinopterygii (ray finned bony fishes) and most (but not all) are members of the Infraclass Teleostei (teleost fishes) within Neopterygii, the most common modern group of fish. The main exceptions are the bowfins which are assigned to the Infraclass Holostei and the controversial sturgeons, which are members of the actinopterygiian Subclass Chondrostei. Being a teleost does not make a fish kosher, since catfish (Order Siluriformes) and eels (Order Anguilliformes) are non-kosher. Even a single order can contain both kosher and nonkosher fish. For example the Order Perciformes contains both perch (kosher) and sculpins (not kosher). Classification alone is thus an unreliable guide to kosher status.

Figure 1 shows the known time range of the families whose members today are considered kosher and that occur in the fossil record. The range goes from today back to the oldest fossil occurrence of that family. Of the fortyfour families that are found as fossils, only 14 go back as far as the Cretaceous, four to the Jurassic, and only one, the bowfins (Family Amiidae) as far back as the Triassic.

This list, of course, only includes families of fish that are found in the water today. For fossil members of these living families and for extinct groups of fish, an observant Jew would demand that we physically demonstrate that it had fins and the correct types of scales. Like most other organisms, fish have a low probability of leaving a fossil record. The numerous biological, chemical and physical processes that occur after death, collectively known as taphonomic processes, rapidly decay the soft tissues, scatter the scales and bones, and eventually destroy even the hard tissues. Fortunately, there are sites that allow exceptional preservation, including complete fish. Paleontologists term these fossil deposits lagerstätten.

One of the most famous lagerstätte is the Green River Formation of Colorado, Wyoming, and Utah (Grande 2013). These fossils are found in fine grained and thinly layered sediments that were deposited in large lakes during the Eocene, about 55 million years ago. The fish preserved in these sediments are often preserved complete, including the fins and scales (Fig. 2a), and would qualify 


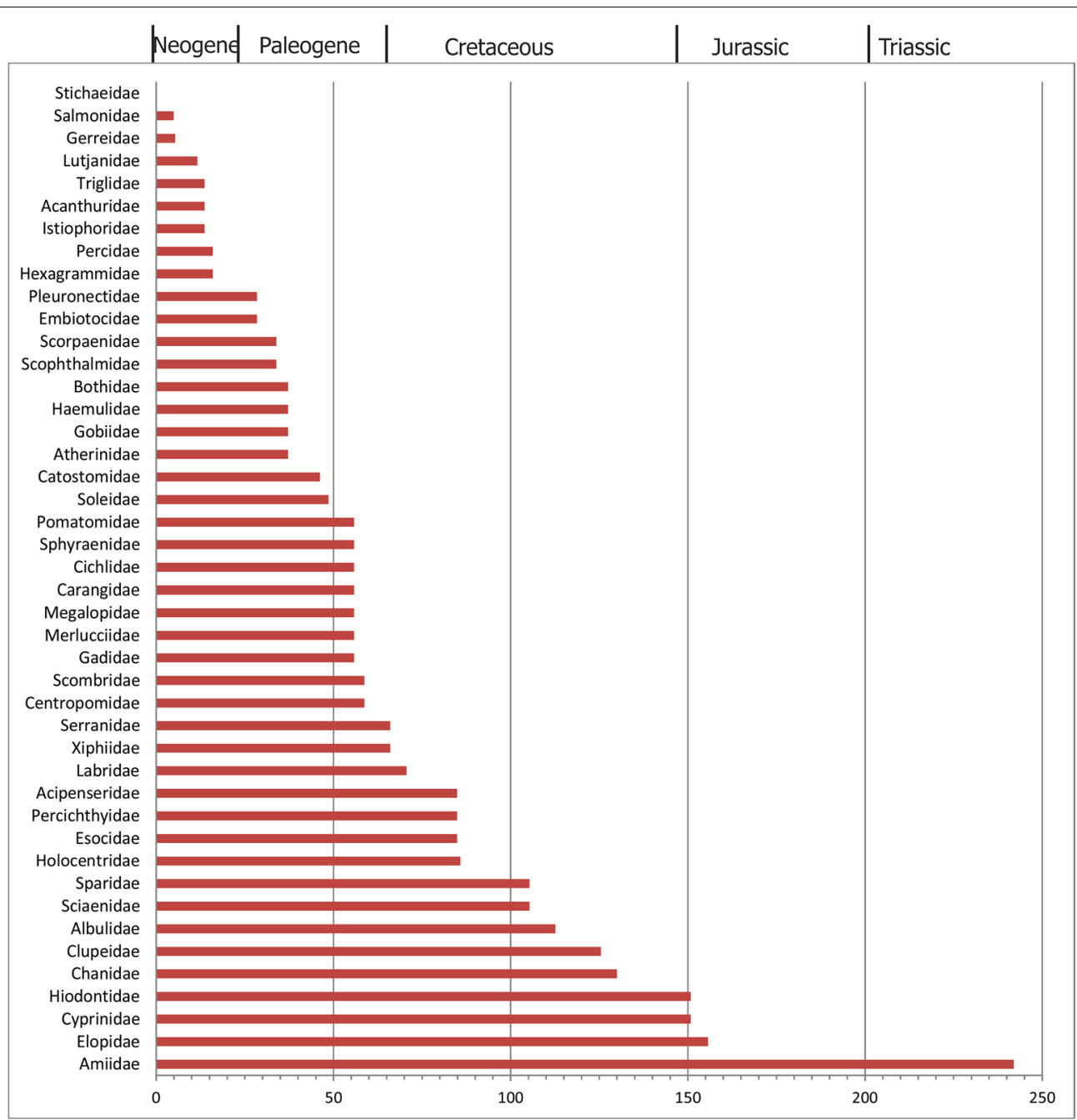

Fig. 1 Fossil record of fish groups with living members considered to be kosher

as kosher. It should be noted that isolated scales are also preserved in many fossil sites (Fig. 2b).

Going much further back, animals that we would call "fish" first appear in the Cambrian, some 520 million years ago (Long 2011; Erwin and Valentine 2013). These early vertebrates not only lacked fins and scales, but had no jaws. Later examples of these fish were covered with bone, often forming an elaborate armor. The oldest rayfinned bony fishes (Actinopterygii) occur in the Late Silurian, about 420 million years ago, but are incomplete (Long 2011). Spectacular examples of complete preservation are known from the Devonian, which show these fish had fins and ganoid scales. Fish that we can definitively recognize as teleosts first appear in the Early Jurassic, but also have ganoid scales (Long 2011; Friedman 2015). The earliest teleost fish with cycloid scales and thus possibly kosher are found worldwide later in the Jurassic; these belong to extinct groups (Arratia et al. 2004; Barthel et al. 1990; Chellouche et al. 2012).

\section{Mammals}

The laws of kashrut prohibit any mammal that does not have both cloven hooves and chew the cud. Cloven hooves, in anatomical terms, refers to animals that show even-toed foot symmetry, where the digits of the foot are arranged symmetrically across an axis between the third and fourth toes, and walk on hooves on the last phalanx of the toes (on tip-toes), a posture known as unguligrade (Figs. 3, 4). Camels, in contrast, although they are cloven footed, are not considered to have "true hooves;" they walk on a broad elastic pad under the middle digits, with two fingernail-like toenails splayed out in front (Klingel 1990; Figs. 3c, 4c). Their foot posture is digitigrade. 


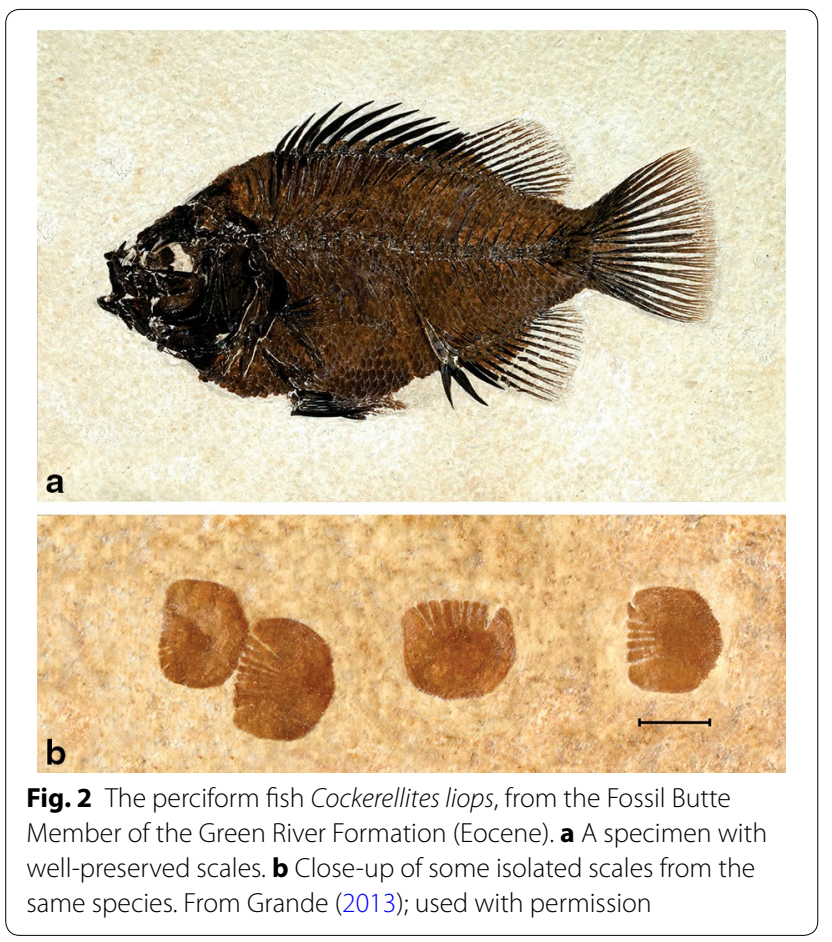

Cud-chewing, or rumination, is a system of fermentation of plant foods in the front portion of the stomach, which is divided into several chambers. Food is chewed, swallowed, fermented, then regurgitated and chewed into finer particles, passing into the next chamber. The fermentation takes advantage of bacteria that live in the chamber to break down cellulose, which mammals cannot ordinarily digest. Modern camels and llamas do chew the cud, although their digestive system differs from the ruminants (ruminants have four digestive chambers as part of the stomach complex, camels have three).

Applying these strictures to modern animals is fairly straightforward, since these two characteristics are restricted only to members of the clade Ruminantia, which is the subgroup of even-toed hoofed mammals that includes the cattle, goats, sheep, antelopes, deer, pronghorn, mouse deer, giraffe (Zivotofsky 2000) and okapi (a clade is a taxonomic group whose members share a common ancestry; in this case it does not have a formal associated Linnaean level, such as family or order). Camels and their relatives belong to a different clade, the Tylopoda.

The determination of whether an ancient mammal had cloven hooves can be done directly using fossils of the limbs, by inspecting the foot symmetry, to make sure it passes between toes 3 and 4, and the shape of the last phalanx of the toes, which should be wide and flat, not pointed or curved (Figs. 3, 4).

Determining whether an animal chewed the cud is much more challenging. Because teeth are what are used to chew and they are by far the most common mammalian remains, they would be the logical place to determine from fossils whether or not an animal chewed the cud. Unfortunately, there are no discernable differences between the teeth of cud-chewers and non-cud chewing artiodactyls. First, one might think that regurgitating so much material back into the mouth might bring excess stomach acid into the mouth and cause recognizable damage to the teeth; however, part of the evolution of rumination (cud-chewing and multi-chambered

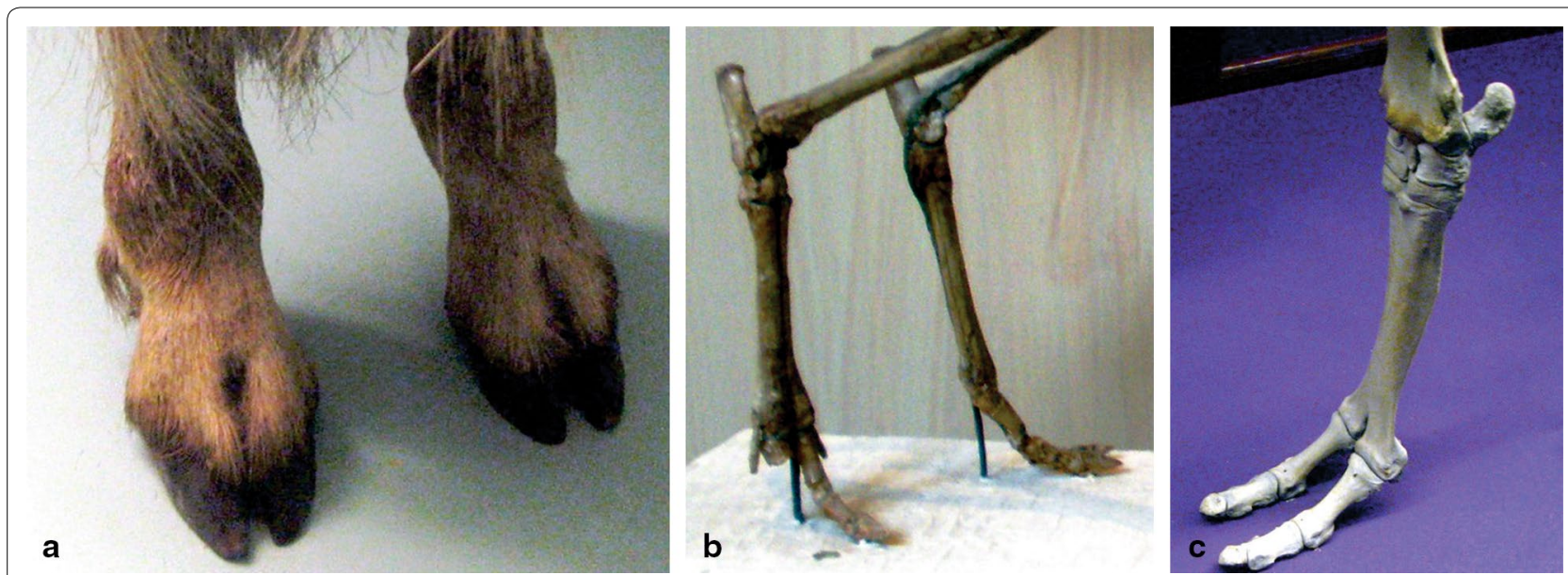

Fig. 3 Cloven hooves. a Cloven hooves of the wild Barbary Sheep. Photo by REP, specimen on display at Field Museum. b Hindfeet of the extinct stem ruminant Hypertragulus calcaratus showing unguligrade foot posture, where the weight is borne on the last phalanx of the toes. This is from the White River Badlands, South Dakota, Eocene-Oligocene in age. Original image public domain, http://commons.wikimedia.org/wiki/ File:Hypertragulus_calcaratus.JPG. c Foot of a modern camel. Photo by REP, specimen on display at Field Museum 


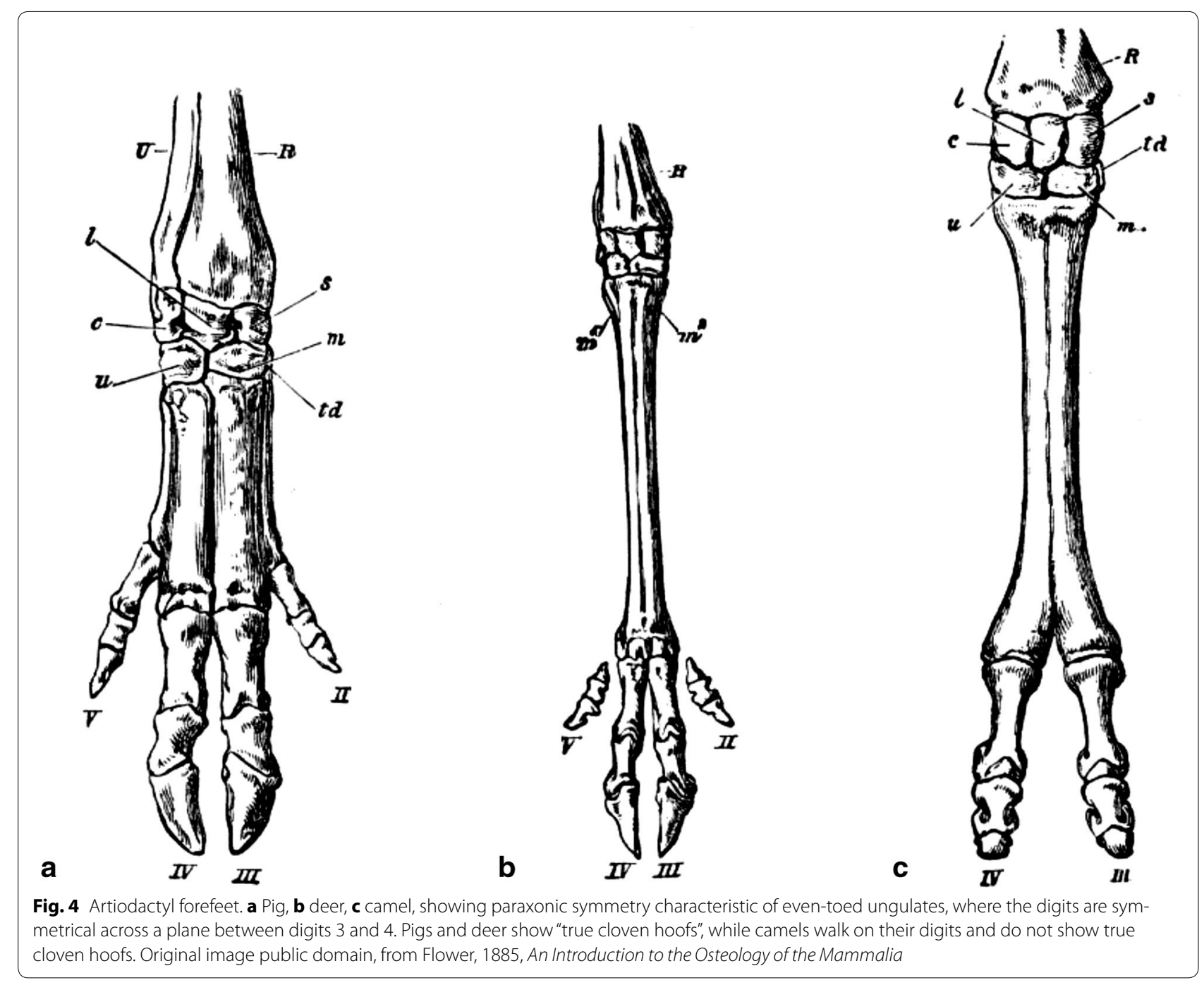

stomachs) included a system of acid reducing mechanisms. The chewed and digested plant matter is regurgitated into the mouth, where the saliva has a high concentration of bicarbonate, which acts as a buffer to the stomach acid coming into the mouth with the cud (McDougall 1948). This reduces the incidence of acid wear on the teeth.

Another option is to test fossil teeth for the ratio of stable isotopes present for a given element, such as the ratio of carbon $\mathrm{C}^{12}$ to $\mathrm{C}^{13}$. These ratios are changed by passing through the cells of living organisms, a process called fractionation. Different types of plants have different ratios of $\mathrm{C}^{12}$ to $\mathrm{C}^{13}$, and these ratios can be seen in the teeth of the animals that eat them. This means that by looking at the ratios of $C^{12}$ to $C^{13}$ in fossil teeth, we can tell what kinds of plants a herbivore was eating (Cerling and Harris, 1999). This type of analysis is widely used in paleontology to better understand mammals and what they ate at different times. There are clear differences in the digestion of ruminants from other mammals, since they not only digest the plant matter but also the bacteria that live in the gut and digest the cellulose. It is not yet technically possible to determine whether an extinct animal chewed the cud from stable isotope analysis, although this approach may someday prove to be useful in determining whether a particular fossil indicates a ruminant digestion.

The best available approach to identifying extinct kosher animals is called the 'extant phylogenetic bracket' (Witmer 1995). This method relies on our ability to use the evolutionary history of a group to predict the characteristics of an extinct member, given what we know of its living relatives. The relationships of artiodactyls to each other are summarized in the phylogeny in Fig. 5 
(a summary of our knowledge of the interrelationships of groups of organisms. We know that all living ruminants chew the cud, and of all the other artiodactyls, only camels also do this. The fossil animal at position A can be confidently assigned within the ruminants based on other diagnostic characteristics, such as having two fused bones in the ankle (the navicular and cuboid). Based on this, we can infer that fossil A should share all the other traits that all ruminants share that cannot be directly observed in the fossil, such as cud-chewing. In contrast, the fossil animal at position $B$ is outside the portion of tree containing modern ruminants and is therefore not surrounded by living members whose characteristics we know; as a result we cannot use this method to predict its characteristics. The terrestrial artiodactyls, the larger clade containing the ruminants, are known in the fossil record only back to the earliest Eocene, and the Ruminantia themselves first appear in the late Eocene (Fig. 3b). Ruminantia are native to Eurasia, Africa and North America, and have been introduced to the remaining continents. South America had its own native ungulate (hoofed) mammals, all of whom are now extinct and none of which had even-toed foot symmetry (Buckley 2015). The beginning of the migration of North American species, the Great American Biotic Interchange (Marshall et al. 1982), brought deer into South America, which would have been the first kosher mammalian species on that continent.

Interestingly, although modern camels are expressly forbidden in the Torah, the oldest camelids in the fossil record are actually unguligrade. The problem for ancient camels is exactly the situation as the fossil in position B in Fig. 5-we have relatively few living camels and most fossil camels are not in the group that contains modern camels. Although modern camels chew the cud, we cannot safely assume that ancient camels would have had the same ability. So, although it is possible that some of the earliest camels in the fossil record might have been considered kosher if they already chewed the cud, this is uncertain.

\section{Birds, Other Dinosaurs, Pterosaurs}

Birds pose an unusual set of difficulties. Unlike fish and mammals, there are no explicit simanim to look for. In a maximally permissive scenario, we could take the position that the 24 kinds of birds specifically forbidden are the only birds prohibited, and thus all extinct birds (especially before any of the extant birds arose) would be kosher. A variation of this would be to also exclude the extinct members of the forbidden extant groups. For this purpose we can examine the relationships of the nearly all 10,000 living bird species that have been worked out in detail (Jetz et al. 2012; Jarvis et al. 2014). Many birds of

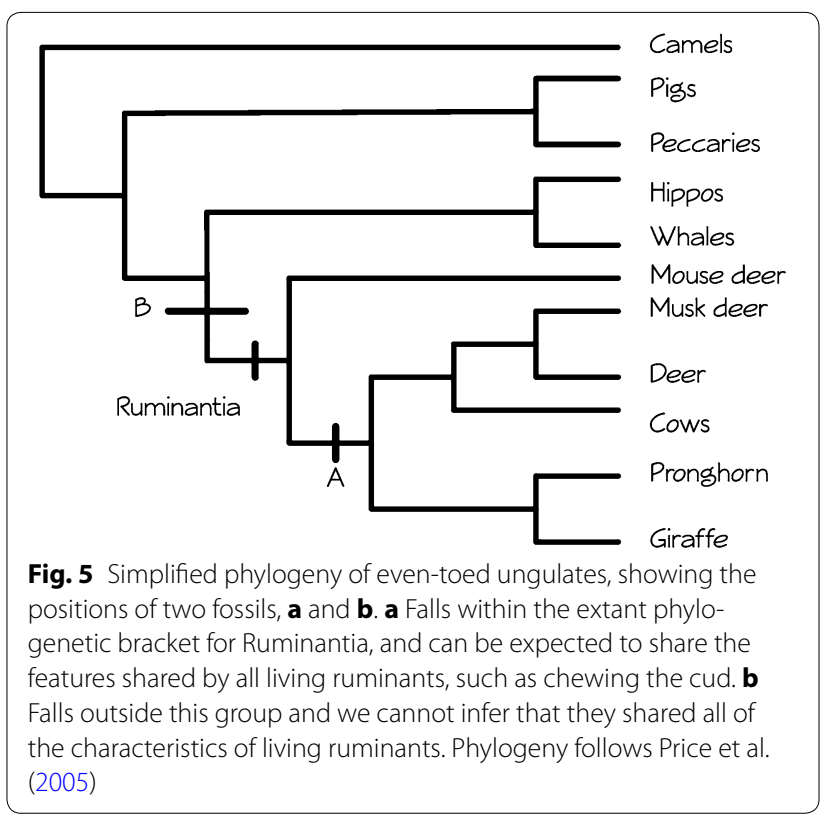

the Cenozoic Era are identifiable to the particular branch of this tree where they belong, including the early representatives of the fowl and waterfowl.

This does leave open the question, however, as how broadly we encompass the term "bird." Do we restrict the concept only to the crown group, which is the group comprised of all living and extinct descendants of the most recent common ancestor of all living birds? Do we want to exclude some or all members of the stem group: that is, species of lines collateral to the extant bird group, but closer to birds than to their closest living relatives (the crocodilians)? If we include stem members, how far down the family tree do we go (Fig. 6)? While there are some branches of the stem that would unquestionably be considered "birds" had they survived, this becomes more problematic further down the tree. And all this is further complicated by the fact that the dietary laws include bats (as prohibited) among the birds despite the fact that bats are biologically mammals. The dietary category of "bird", therefore, is complicated: it is neither simply based on the ability to fly or not (ostriches are included among "birds"), but neither does it strictly map along modern biological nomenclature.

An alternative approach is to assess the ecology and anatomy of extinct taxa (either within the crown or within the stem), and regard those that share the traits of forbidden birds today as being considered forbidden. As we can with mammals, we can identify the evolutionary position of fossil birds with their extant relatives and determine their life habits and soft tissue anatomy based on preserved anatomical features. 


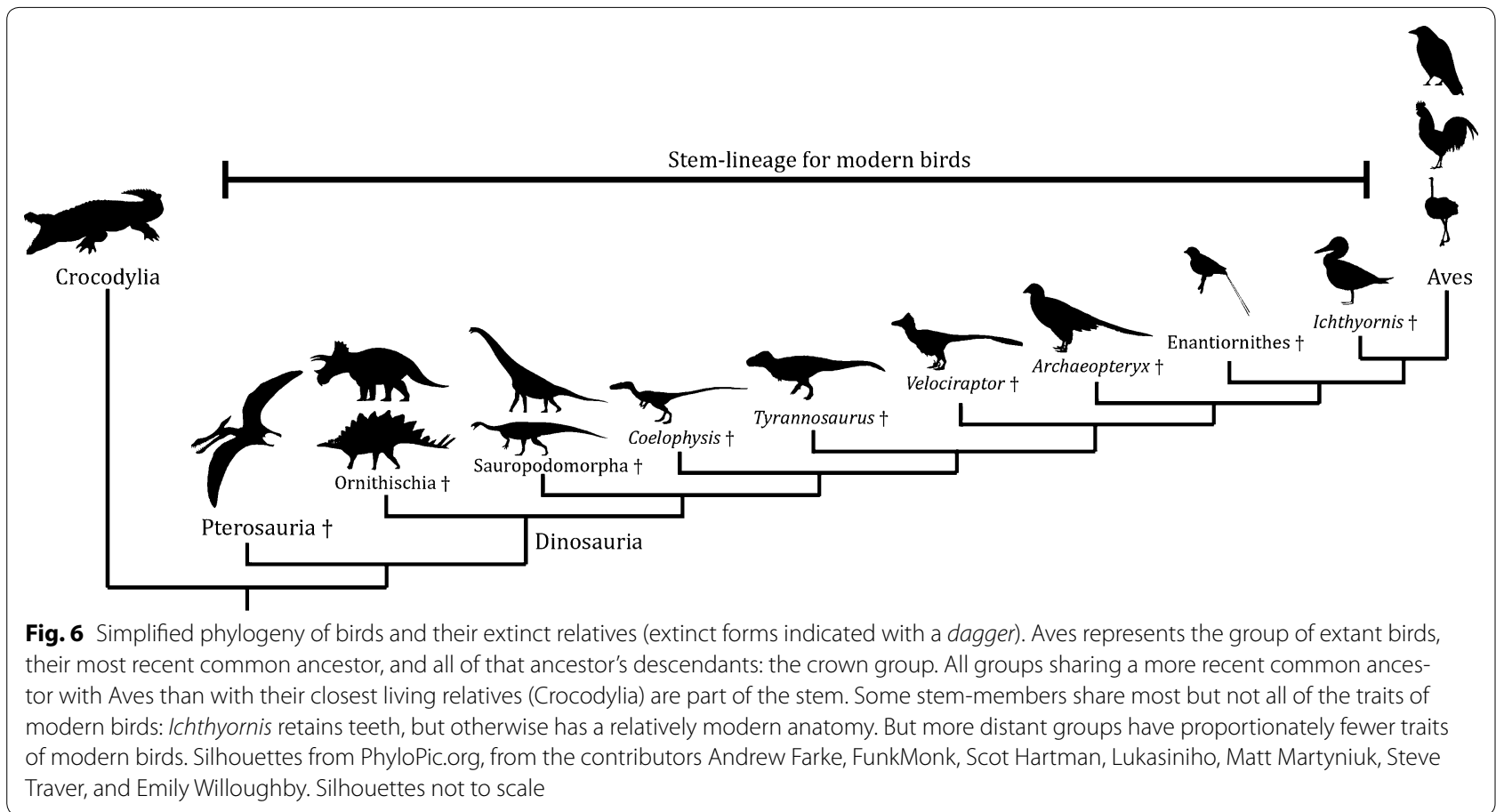

Rabbinic discussions in the Mishnah, the part of the Talmud that focuses on the details of Jewish law and observance, provide some guidelines. In particular, the tractate (sub-section of the Mishnah) that deals with eating of meat is Hullin (or Chullin). Zivotovksy (2014) recently summarized the discussions in Chullin and related rabbinical literature concerning the kashrut of birds. Following his summary, a bird is not kosher if it is dores (a predator), but the demarcation of what makes a predator itself has been debated. Among the alternative definitions of dores are a bird that either (1) seizes its food with its claws and lifts it off the ground to its mouth; (2) holds its prey down with its claws and breaks it into smaller pieces to eat; (3) strikes its prey and feeds on it while it is still alive (with the caveat that the "prey" in this context excludes worms and insects; otherwise chickens would be treif); or (4) claws its prey to death or envenomates its prey (the latter is a moot point, as no known bird engages in this behavior).

These specific sets of behaviors are not directly observable in fossil forms, so we will utilize a more generalized concept of dores: a bird that feeds on the flesh of other vertebrates. As such, fossil birds such as the Teratornithidae (recently extinct scavenging or predaceous, superficially vulture-like birds of sometimes immense size), Pelagornithidae (fish-feeding birds of the Cenozoic Era, the largest of whom rivalled the largest teratornithids as the biggest flying birds in Earth history), and the Phorusrhacidae (predatory "terror birds", some of them fliers but the largest of these up to $3 \mathrm{~m}$ tall and flightless) would all be forbidden.

Once considered predatory, the Gastornithidae (Paleocene Gastornis of Europe and Eocene Diatryma of North America) are now interpreted as likely herbivores (Mustoe et al. 2012). However, these large (2 m tall) flightless birds would likely be forbidden, given that other flightless birds (ostrich) and large long-legged volant birds which nevertheless spend a considerable amount of time walking rather than flying (bustards, storks, herons) are specifically excluded.

The Mishnah further states that a bird is kosher if it has a gizzard with a lining that can be peeled, a crop, and an "extra" toe (Zivotovksy 2014). The gizzard (ventriculus) is a trait shared by all extant birds, and indeed by their closest living relatives the crocodilians. Based on their phylogenetic position, it is thus inferred that the two groups inherited this trait from their common ancestor and passed it down in both lineages. This inference is independently supported by direct fossil evidence of gastroliths (gizzard stones) in various extinct members of the lineage leading to birds: extinct groups of birds and other dinosaurs. Thus, our default assumption would be that any extinct bird or other archosaur (birds, dinosaurs, crocodilians, and pterosaurs) possessed a ventriculus without positive evidence that it had been lost. Whether it could be peeled would depend on direct observation.

The crop (ingluvies) is a more problematic structure. It is an expansion of the esophagus used to store food 
prior to digestion. It is quite large and muscular in seedeating birds, smaller in birds of other diets (such as geese and swans), and nearly absent in the owls. The presence of the ingluvies is very difficult to detect in typical fossils. It is inferred in the extinct Cretaceous seed-eating birds Sapeornis and Hongshanornis (Zheng et al. 2011) and the fish-eating Confuciusornis (Dalsätt et al. 2006) and Yanornis (Zheng et al. 2014) due to a mass of seeds and/or fish bones and scales (respectively) present in the appropriate region of fossil specimens of these. The lack of such masses in other fossil specimens does not indicate that the crop was missing; it may simply indicate that the animal had not recently fed at time of death or that the mass was not preserved.

The "extra toe" is not in fact extra: it is simply pedal digit I, the hallux, more familiar to us as the big toe of humans or the dewclaw of the hind foot of some dogs. The typical interpretation of what is meant by an "extra" toe is that the bird exhibits the anisodactyl condition: the hallux points posteriorly, while digits II-IV point anteriorly (Fig. 7a). The anisodactyl condition gives the birds with this trait an opposable hallux useful for perching (Francisco Botelho et al. 2015). The oldest birds (such as Jurassic Archaeopteryx) lack a fully opposable hallux (Middleton 2001; Mayr et al. 2007), while many Cretaceous birds show a condition where the hallux is partially opposable rather than pointing fully backwards. Given that in such birds the hallux would not be oriented with the remaining toes, this could qualify as "extra," even though it represents a condition not expressed in any living bird species. Other Cretaceous birds have a fully opposable hallux (Fig. 7b).

Therefore, using an approach based on the characteristics outlined above, we might accept as kosher a number of bird species from the Cretaceous Period, but exclude

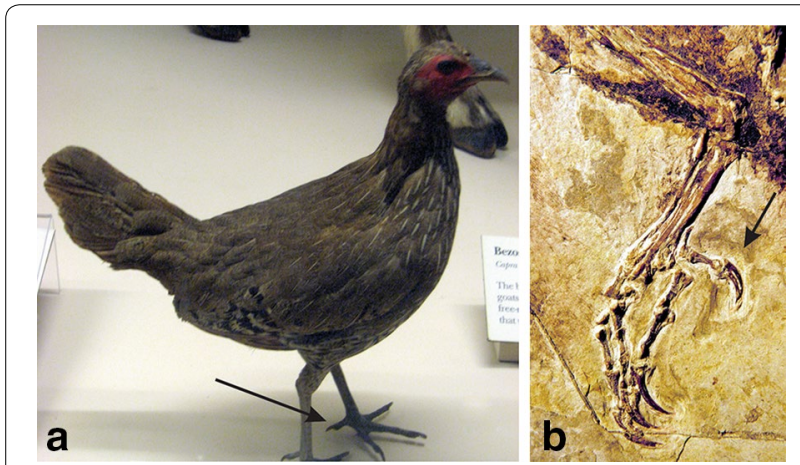

Fig. 7 Modern and fossil bird feet. A. Ceylon junglefowl (Gallus lafayetti) showing the rear facing "extra toe" or hallux (digit 1; arrow). Photography by REP, specimen on display at Field Museum. B. Anisodactyl foot of the Cretaceous stem-bird Confuciusornis. Photograph by TRH. Note the rear-facing hallux for perching (arrow) fish-eaters such as Ichthyornis, the hesperornithines, the longipterygids, confuciusornithids, and Jeholornis. Other primitive Cretaceous birds (the above-mentioned Sapeornis and Hongshanornis) might conceivably be kosher, if we overlook the fact that they have teeth!

But where does birdy-ness begin? Birds are simply one branch of the more inclusive group Dinosauria (Brett-Surman et al. 2012) and there is no single point along the gradations from clearly non-bird theropod dinosaurs (aka "non-avian dinosaurs") to definite birds (Fig. 6). Indeed, this is one of the most completely known transitions in the history of vertebrates (Brusatte et al. 2014), such that primitive birds (or proto-birds) such as Archaeopteryx and primitive members of closely related groups like the dromaeosaurids (Microraptor) and the troodontids (Anchiornis) are nearly identical (Fig. 8). These bipedal feathered dinosaurs (Rauhut et al. 2012) would almost certainly fall under the category "bird" in the Levitical division of the living world into quadrupedal animals, birds, creeping things, and sea life. The majority of these can be easily determined as non-kosher because they were predators; even those that evolved a herbivorous diet (Zanno and Makovicky 2011; Novas et al. 2015) lack the opposable hallux; and would further have fallen under the same aspect as ostriches and bustards as either incapable of flight or rarely using flight.

The other two major branches of Dinosauria are the herbivorous Sauropodomorpha and Ornithischia (Fig. 6). Modern reconstructions show that they had upright limbs: they could not in any way be said to have "creeped (or swarmed) along the ground." Hence they cannot fall under the category of creeping things with modern reptiles. The ancestral members of all dinosaur groups were bipedal. At least some small bipedal ornithischians are known to have had a fluffy body covering (Zheng et al. 2009; Godefroit et al. 2014). Even if we counted them as

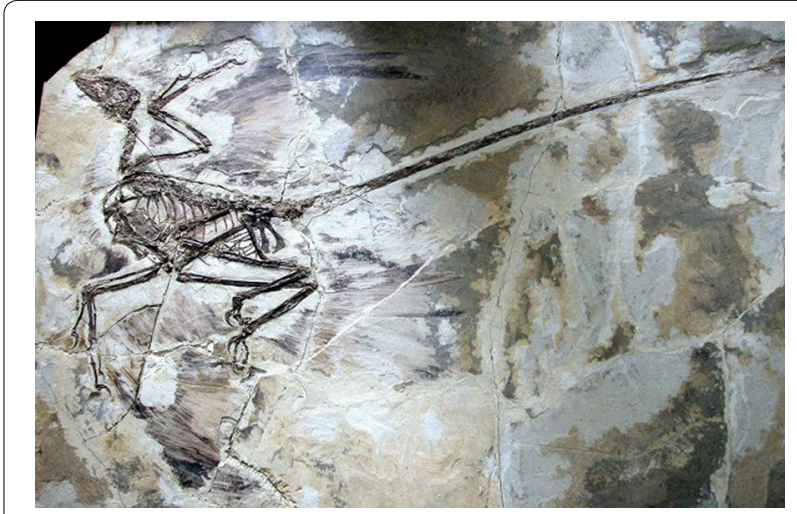

Fig. 8 Dromaeosaurid dinosaur Microraptor from the Cretaceous of China. Photograph by TRH 
birds, they still lacked the opposable hallux. Therefore, we cannot see any non-avian dinosaur being considered kosher. So much for Fred Flintstone's "Bronto-burgers" (if Fred kept kosher)!

What of the Pterosauria? These were flying relatives of the dinosaurs (Witton 2013). While neither birds nor any other dinosaur in the biological sense, they would assuredly fall in the "bird" dietary category just as bats do. And, like bats, their possession of membranous rather than feathered wings, a furry pelage, and (for many species at least) a fish-or flesh-diet, would seem sufficient to place them among the forbidden foods.

\section{Other Fossil Vertebrates}

There is a vast diversity of additional groups of fossil vertebrates, including: (1) crocodilians and their extinct pseudosuchian kin; (2) marine reptiles such as plesiosaurs, ichthyosaurs, placodonts, and the like; (3) lepidosaurs (snakes, lizards, mosasaurs, tuataras, and their extinct relatives); (4) other fossil reptiles; (5) the extinct synapsid ancestors and relatives of mammals; and (6) amphibian-grade animals such as lepospondyls, temnospondyls, and seymouriamorphs (Benton 2014). None of these would be kosher, following Lev. 11:29:30.

\section{Insects}

Although all other insects are forbidden, the Torah specifically permits all grasshoppers, locusts and possibly crickets (some translations disagree; Regenstein pers. com). It also gives a definite simanim: the presence of the jumping hind legs that define the insect Class Orthoptera (Song et al. 2015). Despite common opinion, insects, including orthopterans, have an excellent fossil record
(Grimaldi and Engel 2005). Beautiful examples of fossil crickets are known from the same Green River Shale that yields the well-preserved fossil fish (Fig. 2). The Santana Formation of the Cretaceous of Brazil has excellently preserved fossil grasshopper relatives (Fig. 9). Overall, the oldest known definitive orthopteran is 300 million years old (Late Carboniferous) (Song et al. 2015).

The oldest known fossils, however, are almost certainly younger than the actual first appearance of a group. Because of the vagaries of fossilization, millions of years may separate the origin of a group and its first preservation in the fossil record. Until recently, that was all that could be said about the time of origin based on fossils. The last decade, however, has seen a tremendous advance in our ability to estimate these divergence times; that is, the time of splitting of a group from its closest relatives. This advance results from a combination of new rapid methods to determine sequences in nuclear, mitochondrial, and ribosomal DNA; the development of highly sophisticated and computer intensive methods to construct phylogenies based on those data; and the ability to calibrate the branching patterns in those phylogenies with the fossil record to produce increasingly reliable estimates of divergence times (Wilke et al. 2009).

This approach to estimating divergence times was recently applied by Song et al. (2015) to the evolution of the Orthoptera. Using a combination of mitochondrial and nuclear genes, they produced a detailed phylogenetic tree for nearly the entire group. They then calibrated this tree with nine well-dated fossil occurrences. The results indicate an origin for the Orthoptera in the Carboniferous, at about 316 million years ago, about 15 million years older than the oldest fossil. Of the groups that can
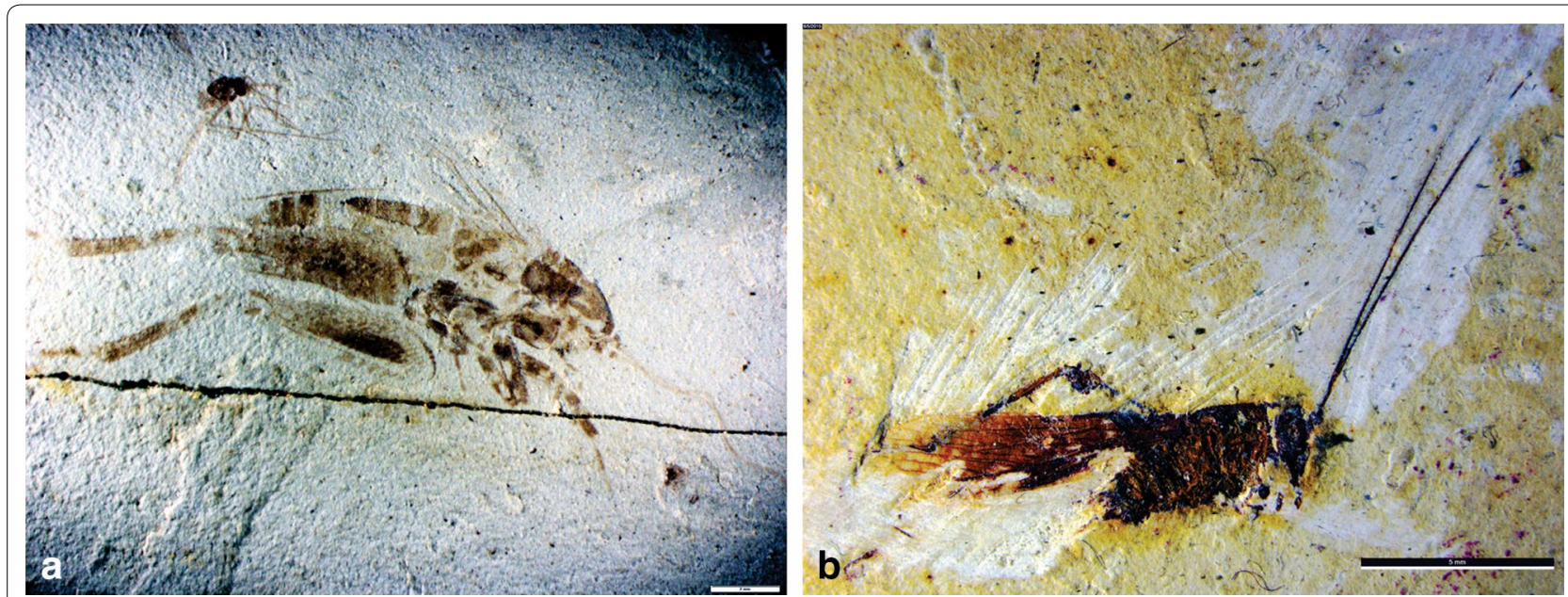

Fig. 9 Fossil Orthoptera. Left cricket from the Eocene Green River Formation, Colorado. Right Elcanid from the Lower Cretaceous Crato Formation of Brazil 
be considered kosher, therefore, the orthopterans go the furthest back in time.

\section{A Virtual Trip Back in Time}

If one wanted to eat kosher (or halal) meat in the world today there is no lack of animals that would be permissible. According the UN Food and Agriculture organization, in 2012 there were about 20 billion domestic fowl (primarily chicken, but also turkeys, geese and ducks), 1.7 billion heads of cattle and buffalo, and 2.1 billion heads of sheep and goats (FAO 2013). It is estimated than $90 \%$ of the mammalian biomass on Earth is made up of humans and their domestic animals, primarily cattle; this value has grown several orders of magnitude since the domestication of these animals about 10,000 years ago (Barnosky 2008; Vince 2011; Xiang et al. 2014). Would the same abundance have been available in the ancient past?

One of the joys of paleontology is that one can take virtual trips through time to visit the life of past geological ages. We will now do so, making selected stops to see what animals we can infer would satisfy the rules of kashrut and thus be acceptable to a hypothetical observant time traveler.

The first stop is 120,000 years ago. This was the peak of the last interglacial warm period before the most recent ice age and before humans first reached the New World or Australia. It was thus prior to the extinction event that wiped out many of the large animals in the world, such as mammoths and giant ground sloths (the Quaternary Megafaunal Extinction; Barnosky 2008; Sandom et al. 2014). Many of these extinct animals are either ancestral to or related to animals that we would recognize as kosher. In Eurasia, we would find the aurochs, Bos primigenius, the ancestor of today's domestic cattle, which went extinct in the $15^{\text {th }}$ century, and the giant Irish Elk (Megaloceros giganteus), the largest deer of all time (Fig. 10a). There would also have been the wild ancestors of modern fowl, sheep, and goats. In the Americas we would be able to feast on abundant ancestral bison (Fig. 10b), as well as a variety of deer, pronghorns, and turkey. Acceptable fish would be found in fresh and marine waters throughout the world.

We now jump back 52 million years, the Early Eocene, to the shores of Fossil Lake in what is now Wyoming (Grande 2013), in what we call the Green River Formation. The lake teems with kosher fish, including abundant perch, herrings, and bass. Crickets chirp along the shore (Plotnick and Smith 2012). There are also abundant modern-looking birds including relatives of modern land and water fowl. Mammals are present, but the Ruminantia have yet to appear on Earth. Thus it would seem that an observant Jew would be limited to a non-mammalian diet, consuming only fishes, birds, and orthopterans.
Our next stop is in the Cretaceous, some 67 million years ago, in the meandering river system that would later form the Hell Creek Formation of Montana and the Dakotas (Nudds and Selden 2008). We are some 1 million years before the asteroid impact that probably wiped out the non-avian dinosaurs and many other groups. Familiar dinosaurs abound, including Tyrannosaurus and Triceratops. Locally there are birds, such as hesperornithines, but none of them anatomically or in terms of diet would meet the requirements of kashrut. Primitive but possibly kosher duck and goose relatives (Vegavis), however, are known from Antarctica at this time (Clarke et al. 2005). There are fish, including bowfins, gars, sawfish, paddlefish, and sturgeon; only the first of these is indisputably kosher. There is no fossil record of crickets or grasshoppers from the Hell Creek, but it is likely they were around.

Our final jump is to 310 million years ago, back to the Late Pennsylvanian, to the deltaic environment of what is called the Mazon Creek biota, in northern Illinois (Wittry 2012). Although vertebrate life exists on land, the reptilelike tetrapods of this period predate any mammal or bird and would certainly "swarm" upon the land. Scales and finned bony fish are known, but none have cycloid scales. There are possible ancestors of crickets and grasshoppers, but their jumping legs were not strongly developed.

Of course, our imaginary time traveler is not restricted to eating meat and fish. As discussed in several essays in Zamore (2011b), vegetarianism is a perfectly acceptable option for Jews (and of course, for anyone else!). The key issue is whether the available plants at each period of Earth history would provide sufficient nutrients, such as protein and total calories, for someone to survive.

First, it should be recognized that most plant foods eaten today have been significantly modified under domestication from their ancestral wild form. This domestication happened within the last 11,000 years and was essentially complete by 4000 years ago (Doebley et al. 2006). Prior to that, there would have been edible wild foods, but they would have had much lower nutritive value and thus required intensive gathering.

Plants with seeds date back to the Devonian. Nearly all edible plant foods however, with the exception of such things as pine nuts and fiddlehead ferns, are derived from members of the vast diversity of flowering plants, the angiosperms. The oldest confirmed fossil angiosperms are 132 million years old (Early Cretaceous), but a possible angiosperm has just recently been identified from over 162 million years ago from China (Liu and Wang 2015). Recent estimates made using molecular clock methods (such as described above for Orthoptera) give estimates of 167-199 million year ago for the origin of flowering plants, in the Jurassic (Bell et al. 2010). Nevertheless, angiosperms were relatively minor components 
of the terrestrial flora until the Cenozoic (Wing and Boucher 1998; Coiffard et al. 2012). Seed size was also small.

The ecological importance of angiosperms rapidly increased during the Cenozoic. A 55 million year old tropical forest contains abundant legumes, seeds, and fruits (Wing et al. 2009). The asterids (lettuce, sunflowers, olives, carrots, potatoes, eggplants, tomatoes, peppers, tobacco, sweet potatoes), which appeared in the Cretaceous, also become widely available during the Early Cenozoic (Manchester et al. 2015), as did nuts. Grasses, which includes wheat, maize, and rice, first occur in the Cretaceous, but grasslands do not spread worldwide until the middle and late Cenozoic (Strömberg 2011).

In sum, as is the case with meats and fish, the further back in time we go, the fewer food options are available. A vegetarian visitor to the Pleistocene or Eocene would have found sufficient resources, given enough time to gather. Before the Cenozoic, however, it is increasingly unlikely that a sustainable diet would have been possible. Our imaginary observant time traveler should pack a lunch!

\section{Discussion}

As evidenced by such things as the Clergy Letter Project, many religious groups accept that familiarity with the Bible does not require a literal interpretation of its contents or a rejection of evolution (Kelley 2000). People of many faiths, including many paleontologists, accept both the reality of biological evolution and the importance of the Bible in their lives (Dodson 1999). Even the non-religious accept that the Bible is a foundational document of western society and some edition of the Bible is probably found in nearly every home. Unfortunately, discussions about the Bible and evolution almost invariably focus on a relative small segment of the biblical text; namely, the sections dealing with creation and their conflict, when read literally, with scientific views of the age and history of the Earth. The result has been the large literature on "evolution vs. creationism." (e.g., Scott 2004; Scott and Branch 2006) and the public perception of the incompatibility of faith and acceptance of evolution.

We would like to suggest a novel approach: that knowledge of the biblical texts can also be used to spark an interest in the concepts and methods of paleontology and evolutionary biology. Focusing on areas of the texts other than Genesis may make these ideas more interesting and palatable to people of faith. In particular, the topic we discuss here, "Kosher paleontology," could be used for conversations about evolution that are lighter and more entertaining. We can envision this topic being presented as part of adult education to diverse faith communities, as well as in wider public venues such as the numerous local "science pubs." The time-travel aspect might be appealing to science fiction fans.

This approach should attract interest well beyond the Jewish community, only a minority of which themselves strictly follow the dietary laws. First of all, "kosher" is
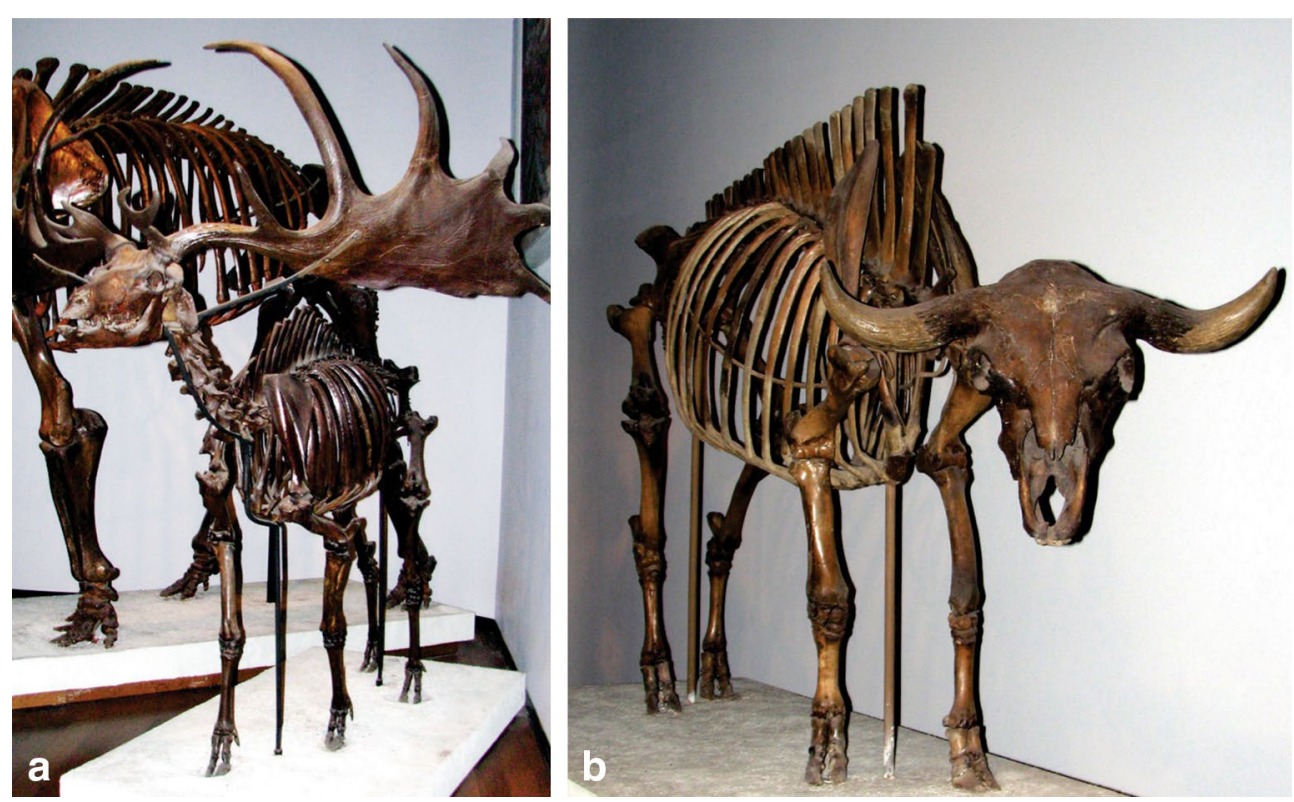

Fig. 10 Extinct Pleistocene ruminants. a Irish Elk Megaloceros giganteus. b Ancestral bison Bison antiquus. Specimens on display at the Field Museum. Photos by REP 
a widely familiar slang term among Americans, coming to mean legitimate or proper, as in "is downloading this movie kosher?" Second, kosher foods are a major growth market among the wider population. According to Forbes, products identified as kosher are increasingly common in supermarkets and were projected to generate $\$ 17$ billion dollars in sales in 2013 . The majority of purchasers are not Jewish or Muslim and do not buy them for religious reasons, but for inferred superior quality or health benefits (Faw 2013). We see the topic of "Kosher paleontology" as a hook or gateway into field of paleontology and an exploration of its data and methods.

\section{Authors' Contributions}

All authors contributed equally to the drafting of the manuscript. All authors read and approved the final manuscript.

\section{Author details}

${ }^{1}$ Department of Earth and Environmental Sciences, University of Illinois at Chicago, 845 W. Taylor St., Chicago, IL 60607, USA. ${ }^{2}$ Department of Biological Sciences, University of Calgary, 2500 University Dr. NW Calgary, Alberta T2N 1N4, Canada. ${ }^{3}$ Department of Geology, University of Maryland, 8000 Regents Drive, College Park, MD 20742, USA. ${ }^{4}$ Department of Paleobiology, National Museum of Natural History, Smithsonian Institution, Washington, DC 20013, USA.

\section{Authors' Information \\ REP is an invertebrate paleontologist at the University of Illinois at Chicago. He has an eclectic range of interests, including functional morphology, fossil preservation, and landscape ecology. JMT is a vertebrate paleontologist at the University of Calgary. Her research focuses on understanding the causes of organismal diversity patterns found over geologic time, particularly that of ungulates. TRH is a vertebrate paleontologist at the University of Maryland, College Park. He studies the phylogeny and functional morphology of the theropod dinosaurs, especially Tyrannosauridae.}

\section{Acknowledgements}

We would like to thank Anthony Martin, Emory University for first raising this question. Our research into the arcana of the kosher rules were greatly helped by discussions with Rabbi Mary Zamora, Rabbi Max Weiss, and Joe M. Regenstein; the latter two also commented on the manuscript. Nathan Jud helped with the discussion of ancient plants. JMT thanks Michael Chabon and Neil Gaiman for their interest and encouragement. Reviewers David Fastovsky and Patricia Kelley are warmly thanked for their comments. No pork was consumed by REP or JMT in the writing of this paper.

\section{Compliance with Ethical Guidelines}

Competing Interests

The authors declare that they have no competing interests.

Received: 14 July 2015 Accepted: 21 September 2015

Published online: 24 September 2015

\section{References}

Arratia G, Scasso RA, Kiessling W. Late Jurassic fishes from Longing Gap, Antarctic Peninsula. J Vertebr Paleontol. 2004;24(1):41-55. doi:10.1671/1952-4.

Barnosky AD. Megafauna biomass tradeoff as a driver of Quaternary and future extinctions. Proc Natl Acad Sci. 2008;105(Supplement 1):11543-8. doi:10.1073/pnas.0801918105.

Barthel KW, Swinburne NHM, Conway Morris S. Solnhofen. Cambridge, UK: Cambridge University Press; 1990.

Bell CD, Soltis DE, Soltis PS. The age and diversification of the angiosperms rerevisited. Am J Bot. 2010;97(8):1296-303. doi:10.3732/ajb.0900346.
Benton MJ. Vertebrate Palaeontology. 4th ed. Chichester, UK: Wiley-Blackwell; 2014.

Betancur R, Broughton RE, Wiley EO, Carpenter K, Lopez JA, Li C, et al. The tree of life and a new classification of bony fishes. PLoS Currents Tree of Life, 2013 Apr 18. Edition 1, 2013. 1.doi:10.1371/currents.tol.53ba26640df0cca ee75bb165c8c26288.

Botelho J, Smith-Paredes D, Soto-Acuña S, Mpodozis J, Palma V, Vargas AO. Skeletal plasticity in response to embryonic muscular activity underlies the development and evolution of the perching digit of birds. Science Reports. 2015; doi:10.1038/srep09840.

Brody S. Ask the Rabbi: what characteristics make a bird kosher? Jerusalem Post, 2011 (07/29/2011).

Brusatte Stephen L, Lloyd Graeme T, Wang Steve C, Norell Mark A. Gradual assembly of avian body plan culminated in rapid rates of evolution across the dinosaur-bird transition. Curr Biol. 2014;24(20):2386-92. doi:10.1016/j. cub.2014.08.034.

Buckley M. Ancient collagen reveals evolutionary history of the endemic South American 'ungulates'. Proc Royal Soc B. 2015;282(1806). doi:10.1098/rspb.2014.2671.

Cerling TE, Harris JM. Carbon isotope fractionation between diet and bioapatite in ungulate mammals and implications for ecological and paleoecological studies. Oecologia. 1999;120:347-63.

Chellouche P, Fürsich FT, Mäuser M. Taphonomy of neopterygian fishes from the Upper Kimmeridgian Wattendorf Plattenkalk of Southern Germany. Palaeobiodiversity and Palaeoenvironments. 2012;92(1):99-117.

Clarke JA, Tambussi CP, Noriega Jl, Erickson GM, Ketcham RA. Definitive fossil evidence for the extant avian radiation in the Cretaceous. Nature. 2005;433(7023):305-8. doi:10.1038/nature03150.

Coiffard C, Gomez B, Daviero-Gomez V, Dilcher DL. Rise to dominance of angiosperm pioneers in European Cretaceous environments. Proc Natl Acad Sci. 2012;109(51):20955-9.

Dalsätt J, Zhou Z, Zhang F, Ericson PGP. Food remains in Confuciusornis sanctus suggest a fish diet. Naturwissenschaften. 2006;93:444-6.

Dodson P. Faith of a paleontologist. the evolution-creation controversy II: perspectives on science, religion, and geological education. Paleontol Soc Papers. 1999;5:183-96.

Doebley JF, Gaut BS, Smith BD. The molecular genetics of crop domestication. Cell. 2006;127(7):1309-21.

Donin HH. To Be a Jew. New York: Basic Books; 1972.

Erwin D, Valentine JW. The cambrian explosion. Genwodd Village, Colorado: Roberts and Company; 2013.

FAO. FAO statistical yearbook 2013. Rome: Food and Agriculture Organization of the United Nations; 2013.

Faw L. Is kosher the next big food trend? 2013; http://www.forbes.com/sites/ larissafaw/2013/12/02/is-kosher-the-next-big-food-trend/.

Friedman M. The early evolution of ray-finned fishes. Palaeontology. 2015;58(2):213-28. doi:10.1111/pala.12150.

Froese R, Pauly D. FishBase. 2014. http://www.fishbase.org. Accessed 1 June 2015.

Godefroit P, Sinitsa SM, Dhouailly D, Bolotsky YL, Sizov AV, McNamara ME, Benton MJ, Spagna P. A Jurassic ornithsichian dinosaur from Siberia with both feathers and scales. Science. 2014;345(6195):451-5.

Grande L. The lost world of fossil lake. Chicago: The University of Chicago Press; 2013.

Grimaldi D, Engel MS. Evolution of the insects. Cambridge: Cambridge University Press; 2005.

Hoffman G. Kosher conundrums. Jerusalem Post. 2010, 07/30/2010.

Jarvis ED, Mirarab S, Aberer AJ, Li B, Houde P, Li C, et al. Whole-genome analyses resolve early branches in the tree of life of modern birds. Science. 2014;346(6215):1320-31. doi:10.1126/science.1253451.

Jetz W, Thomas GH, Joy JB, Hartmann K, Mooers AO. The global diversity of birds in space and time. Nature. 2012;491(7424):444-8. doi:10.1038/ nature11631.

Jewish Publication Society. Tanakh: the holy scriptures. Philadelphia: Jewish Publication Society; 1985.

Kelley PH. Studying evolution and keeping the faith. Geotimes, 2000;45(12):22-23, 41.

Klingel H. Camels. In: SP Parker (Ed.), Grzimek's Encyclopedia of Mammals. 1990 (vol. 5, pp. 85-96). New York: McGraw-Hill.

Kraemer D. Jewish eating and identity through the ages. New York: Routledge; 2007. 
Liu Z, Wang X. A perfect flower from the Jurassic of China. Hist Biol. 2015; doi:1 0.1080/08912963.2015.1020423.

Long JA. The rise of fishes. 2nd ed. Baltimore: The Johns Hopkins University Press; 2011.

Manchester SR, Grímsson F, Zetter R. Assessing the fossil record of asterids in the context of our current phylogenetic framework. Ann Mo Bot Gard. 2015;100(4):329-63.

Marshall LG, Webb SD, Sepkoski JJ, Raup DM. Mammalian evolution and the great American interchange. Science. 1982;215(4538):1351-7. doi:10.1126/science.215.4538.1351.

Mayr G, Pohl B, Hartman S, Peters DS. The tenth skeletal specimen of Archaeopteryx. Zool J Linnean Soc. 2007;149(1):97-116.

McDougall El. Studies on Ruminant Saliva. 1. The composition and output of sheep saliva. Biochem J. 1948;43(1):99-109.

Middleton KM. The morphological basis of hallucal orientation in extant birds. J Morphol. 2001;250:51-60.

Mustoe G, Tucker D, Kemplin K. Giant Eocene bird footprints from northwest Washington, USA. Palaeontology. 2012;55(6):1293-305.

Novas FE, Salgado L, Suárez M, Angolín FL, Ezcurra MD, Chimento NR, de la Cruz R, Isasi MP, Vargas AO, Rubilar-Rogers D. An enigmatic plant-eating theropod from the Late Jurassic of Chile. Nature. 2015;522:331-4.

Nudds JR, Selden PA. The Fossil Ecosystems of North America. Chicago: University of Chicago Press, 2008.

Orthodox Union. An analysis of kaskeses - past and present. 2013 https://oukosher.org/blog/consumer-kosher/ an-analysis-of-kaskeses-past-and-present.

Plotnick RE, Smith DM. Exceptionally preserved fossil insect ears from the Eocene Green River Formation of Colorado. J Paleontol. 2012;86(1):19-24.

Price SA, Bininda-Emonds ORP, Gittleman AL. A complete phylogeny of the whales, dolphins and even-toed hoofed mammals (Cetartiodactyla). Biol Rev. 2005;80(3):445-73. doi:10.1017/s1464793105006743.

Rauhut OWM, Foth C, Tischlinger H, Norell MA. Exceptionally preserved juvenile megalosauroid theropod dinosaur with filamentous integument from the Late Jurassic of Germany. Proc Natl Acad Sci. 2012;109: $11746-51$.

Regenstein JM, Chaudry MM, Regenstein CE. The kosher and halal food laws. Comprehensive reviews in food science and food safety. 2003;2:111-27.

Sandom C, Faurby S, Sandel B, Svenning J-C. Global late Quaternary megafauna extinctions linked to humans, not climate change. Procee Royal Soc B Biol Sci. 2014;. doi:10.1098/rspb.2013.3254.

Scott EC. Evolution vs. Creationism. Berkley: University of California Press; 2004. Scott EC, Branch G, editors. Not in our classrooms. Boston: Beacon Press; 2006.

Song H, Amédégnato C, Cigliano MM, Desutter-Grandcolas L, Heads SW, Huang Y, et al. 300 million years of diversification: elucidating the patterns of orthopteran evolution based on comprehensive taxon and gene sampling. Cladistics. 2015. doi:10.1111/cla.12116.
Strömberg CAE. Evolution of grasses and grassland ecosystems. Annu Rev Earth Planet Sci. 2011;39:517-44.

Telushkin J. Jewish literacy. New York: William Morrow and Company; 1991.

Vince G. An Epoch debate. Science. 2011;334(6052):32-7. doi:10.1126/ science.334.6052.32.

Wilke T, Schultheiß R, Albrecht C. As time goes by: a simple fool's guide to molecular clock approaches in invertebrates. Am Malacol Bull. 2009;27:25-45.

Wing SL, Boucher LD. Ecological aspects of the Cretaceous flowering plant radiation. Ann Rev Earth Planet Sci. 1998;26:379-421.

Wing SL, Herrera F, Jaramillo CA, Gómez-Navarro C, Wilf P, Labandeira CC. Late Paleocene fossils from the Cerrejón Formation, Colombia, are the earliest record of Neotropical rainforest. Proc Natl Acad Sci. 2009;106(44):1862732. doi:10.1073/pnas.0905130106.

Witmer LM. The extant phylogenetic bracket and the importance of reconstructing soft tissues in fossils. In: Thomason JJ, editor. Functional morphology in vertebrate paleontology. Cambridge: Cambridge University Press; 1995. p. 19-33.

Witton MP. Pterosaurs: Natural History, Evolution, Anatomy. Princeton: Princeton University Press; 2013.

Wittry J. The Mazon Creek Fossil Fauna. Downers Grove: Earth science club of Northern Illinois; 2012

Xiang H, Gao J, Yu B, Zhou H, Cai D, Zhang Y, et al. Early Holocene chicken domestication in northern China. Proc Natl Acad Sci. 2014;111(49):175649. doi:10.1073/pnas.1411882111.

Zamore ML. An overview of ritual kashrut. The sacred table. New York: CCAR Press; 2011a. p. 123-38.

Zamore ML, editor. The Sacred Table. New York: CCAR Press; $2011 \mathrm{~b}$.

Zanno LE, Makovicky PJ. Herbivorous ecomorphology and specialization patterns in theropoddinosaur evolution. Proc Natl Acad Sci. 2011;108:232-7.

Zheng X, You H, Xu X, Dong Z. An Early Cretaceous heterodontosaurid dinosaur with filamentous integumentary structures. Nature. 2009:458(7236):333-6.

Zheng X, Martin LD, Zhou Z, Burnham DA, Zhang F, Miao D. Fossil evidence of avian crops from the Early Cretaceous of China. Proc Natl Acad Sci. 2011;108(38):15904-7. doi:10.1073/pnas.1112694108.

Zheng X, O'Connor JK, Huchzermeyer F, Wang X, Wang Y, Zhang X, Zhou Z . New specimens of Yanornis indicate a piscivorous diet and modern alimentary canal. PLoS One. 2014;9(4):e95036.

Zivotofsky AZ. Kashrut of exotic animals: the buffalo. The Journal of Halacha and Contemporary Society, 38 (Fall 1999/Sukkot 5760). 1999. http://www. kashrut.com/articles/buffalo/.

Zivotofsky AZ. What's the truth about giraffe meat? Jewish Action, 5761/2000 (Fall), 37. 2000. http://www.kashrut.com/articles/giraffe/.

Zivotofsky AZ. Is turkey kosher? 2014. http://www.kashrut.com/articles/ turk_intro/.

\section{Submit your manuscript to a SpringerOpen ${ }^{\circ}$ journal and benefit from:}

- Convenient online submission

- Rigorous peer review

- Immediate publication on acceptance

- Open access: articles freely available online

- High visibility within the field

- Retaining the copyright to your article

Submit your next manuscript at $>$ springeropen.com 